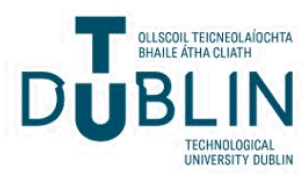

Technological University Dublin

ARROW@TU Dublin

2018-04-18

\section{Events, social connections, place identities and extended families}

Bernadette Quinn

Technological University Dublin, bernadette.quinn@tudublin.ie

Theresa Ryan

Technological University Dublin, theresa.ryan@tudublin.ie

Follow this and additional works at: https://arrow.tudublin.ie/tfschhmtart

Part of the Human Geography Commons

\section{Recommended Citation}

Bernadette Quinn \& Theresa Ryan (2018) Events, social connections, place identities and extended families, Journal of Policy Research in Tourism, Leisure and Events, Published online April 2018. DOI: 10.1080/19407963.2018.1465067

This Article is brought to you for free and open access by the School of Tourism \& Hospitality Management at ARROW@TU Dublin. It has been accepted for inclusion in Articles by an authorized administrator of ARROW@TU

Dublin. For more information, please contact

arrow.admin@tudublin.ie, aisling.coyne@tudublin.ie, gerard.connolly@tudublin.ie.

Funder: Failte Ireland

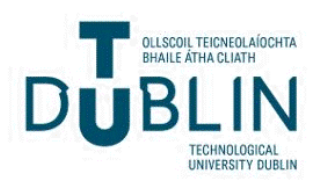


Title: Events, social connections, place identities and extended families

\begin{abstract}
The study reported here investigates the role that planned social gatherings play in shaping social connections, forging group identity and re-affirming connections with significant 'home' places within families where relationships extend across space. Empirically, it draws on a study of the Gathering, a 2013 national tourism initiative that encouraged people in Ireland to organise 'gatherings' to attract 'home' family members scattered across the globe. It reports data generated using mixed methods administered in two Irish counties. The findings demonstrate the profound meanings that the gatherings had for participating family members. The events served to strengthen existing family ties and to create new ones both between family members separated by geographic distance and spread across family generations. They further served to renew and revitalise connections with the family 'home' place, to enhance a sense of belonging for the family units studied and to strengthen family identity.
\end{abstract}

Keywords: Events; Families; Social capital; Place; Identity; Ireland 


\section{INTRODUCTION}

In contemporary society, festivals and events continue to proliferate and become increasingly embedded into routine social practices. While many researchers have studied the social connections fostered through festival and event activity, few have focused on the family as the unit of analysis. This is despite the fact that 'family togetherness' consistently emerges as a key motive underpinning festival attendance (e.g. Lee, Arcodia and Lee 2012). The study reported here focuses on families where relationships are extended and stretched by diasporic ties across varying geographical distances. It aims to further understandings of how festivals create opportunities for social connections to be enhanced in this context. Empirically, it draws on a study of The Gathering, a 2013 tourism initiative that encouraged people in Ireland to organise 'gatherings' aimed at attracting 'home' friends and families scattered across the globe. The initiative produced in excess of 5,000 communal celebrations that ranged greatly in size. A significant proportion of the gatherings were family celebrations and it is a sample of these that are discussed here. Unlike most of the literature dealing with diaspora and connections with home, this paper reports data collected not only from those who live away from the 'home' place, but also from those who reside in, or close to, that 'home' place. Before reporting the study findings, the paper begins with a review of relevant literature.

\section{FESTIVALS, EVENTS AND SOCIAL CONNECTIONS}

Researchers like Lavenda (1977) have long argued that festivals are vehicles for producing and remembering social meaning and for realizing community through shared play and celebration. Since at least the late 1980s, researchers have written about the intensification of social relations generated by festival and event activities, highlighting social interactions, social bonding and community bonding as characteristic features, as well as the attendant stimulation of civic pride and community spirit. Festivals are settings where social connections are made, social networks are forged, group identity is constructed and negotiated, and solidarity between individuals and groups is sensed. One strand in the literature uses social capital ideas to further understandings of the social networks that underpin festival activity. Bourdieu (1986) and Coleman (1988) were early proponents of the concept of social capital which remains a complex and contested term. Bourdieu (1986) defined it as reciprocal relationships embedded in social networks, and underscored its exclusionist aspects, while Coleman (1988) viewed it more as a public good, arguing that actors can use aspects of these networks as resources for action, e.g. to acquire information or access other networks. As Falk and Kilpatrick (2000) argued, positive interactions between individuals build social relationship networks. Habermas (1972) 
associated these networks with the development of reciprocity, trust and shared constructions of reality, while Coleman (1988) understood them to include three dimensions: obligations, expectations and trust worthiness; information; and norms and sanctions. Granovetter (1973) conceptualised the ties that link nodes in a social network as strong and weak ties. The former are durable and involve frequent interactions with emotional implications while the latter involve more informal, shallower kinds of interactions. Strong tie relationships are associated with bonding capital. As Wilks (2011) explains, bonding social capital is inward looking, serving to bolster solidarity among people who are already similar, although it can also serve to exclude others. Bridging social capital, in contrast, is associated with weak tie relationships. It is outward looking and involves people making connections with others previously unknown to them.

Festivals and events have been shown to be settings where social capital is formed through the development of community resources, promotion of social cohesion and the creation of opportunities for public celebration. Rao (2001) was one of the first to recognise in festivals the ability to reinforce ties within a community in his study of festivals in rural India. He found that festivals serve to connect households and build social networks that generate tangible economic and social returns. More recently, social capital has become more prominent as a theoretical lenses through which to study the social dimensions of festivals (Finkel, 2010; Mykletun, 2009; Quinn and Wilks, 2013; Wilks, 2011; Black 2016; Wilks and Quinn 2016). Several researchers have investigated the social interactions between festival audience members using social capital ideas (Wilks 2011, Mollitor, Rossi and Branton 2011). The latter study of community events, including festivals, found that attendees increased access to resources that could enhance their living circumstances. Other researchers have used social capital to investigate the perspective of festival organizers (Mykletun 2009), and community residents (Finkel 2010). Often, when 'community' is under investigation in festival studies, the place-based community is the focus of study but Wilks and Quinn (2016) highlight the social relations that can develop between long-term repeat visitors, and between such visitors and members of the local community.

Not withstanding the contested nature of festival spaces (Duffy and Waitt 2011), most of these studies point to the social connectivity engendered by festivals and the social cohesiveness that this can potentially generate. They show festivals to be settings where bonding capital can be generated for community members and where bridging capital can also be produced. In a separate line of enquiry in the literature, festivals have also been linked to the development of sense of community. Winkle and Woosnam (2013) draw on McMillan and Chavis' (1986) 
conceptualization of sense of community as comprising four constructs: membership, influence, integration and needs fulfilment and shared emotional connection. Communities are understood to be defined by informal networks based on trust and collective action and to be underpinned by complex, local, individual interactions (Rodríguez-Perez and Storper 2006). Writing about festivals, Pedrana (2015) reiterates this definition, stressing the importance of distinguishing between community (the informal), and society (the formal) when investigating how social capital emerges. Black (2016) analysed the knowledge exchange networks engendered through her four case study festivals finding that both formal and informal means were important.

If similarities can be highlighted between the generation of social capital and sense of community, so too can overlaps be identified between the generation of social capital and for example, pride in place and identity building (Finkel 2010). Both Wilks (2011) and Mykletun (2009) point to the inevitable links between social and cultural capital, commenting on the complex role of the latter in informing social capital. The importance of place in underpinning the social stability of the networks identified (Wilks and Quinn 2016) has also been discussed.

\section{FESTIVALS \& EVENTS, SOCIAL CONNECTIONS AND EXTENDED FAMILIES}

To date, little if any attention has been paid to how the social relations that underpin families fare in festival and event contexts. With one exception: the literature on festival and event motivation where socialization/sociability and family togetherness have consistently featured alongside a number of other dimensions including novelty, excitement and escape as key factors explaining festival attendance (Uysal et al. 1993; Mohr et al. 1993; Backman et al. 1995; Lee 2000, Lee et al. 2004). Beyond this, few studies exist, and those that do, approach family in disparate ways, with Foster and Robinson (2010), for example, studying the role that children play in family decisions to attend events, and Taylor, McArdle, Richer, Brennan and Weier (2006) considering child - parent relationships in the context of a festival of early childhood. As already mentioned, many of the studies investigating the social connections built through festivals focus on communities, and occasionally families are mentioned in this context (Gursoy, Kim and Uysal 2004). However, the relative absence of family from festival and event studies is a notable gap in the literature.

The study reported here aims to partially address this gap by studying families whose relationships are extended and stretched by diasporic ties across varying geographical distances. 
As Morgan, Pritchard and Pride (2003, p. 71) point out, destination marketing strategies often conceive of events as effective ways of appealing to diasporic sentiment and emotion, with members of the diaspora being 'particularly open to emotional marketing appeals'. Thus, the Irish Gathering of 2013 was following in the footsteps of the Welsh Tourist Board's 2000 campaign to attract 'home' the Welsh diaspora and the 2009 'Scottish Year of Homecoming'. Studies undertaken on events aimed at attracting diaspora make it clear that in participating, people are actively intent on identity affirmation. Wamwara-Mbugua and Cornwell (2009) suggest that individuals participate in international festivals as a way of extending themselves, and have a vested interest in producing a collective cultural identity. Schofield and Thompson (2007) wrote about the importance of culture in the motivation to visit an event. They argued that if one's culture is represented at an event, then one is more likely to visit because of the significance and interest of the culture that is being celebrated.

As Etemaddar, Tucker and Andrews (2016) have argued, conceiving of diaspora tourism simply in terms of physical trips back to a 'home' place is overly simplistic in that it ignores the multitude of imaginary, material and virtual ways through which people construct notions of home. Nevertheless, the physical trips taken by members of diaspora to 'home' places widely referred to as diasporic tourism (Mouffakir 2011, Schevyens 2007) cannot be overlooked. The tourism literature on VFR identifies socialization as a strong motive and consolidating and reinvigorating social networks to be a priority (Duval 2003, Lee 2004). As Crang (2006, p. 62) writes, 'relations of domesticity, intimacy and belonging progressively extend beyond the material site where we live'. For members of diasporic communities travelling 'home', relations of belonging clearly extend beyond the material place where they routinely dwell to encompass a reaching out to significant others elsewhere. Perhaps less understood is how the return holiday trips home made by family members living 'away' affect those family members who remain living in the 'home place'.

Thus, one aim of this study is to further understandings of the role that events play in stretching and extending family connections into and out of the significant place called 'home'. Place can be understood to signify meaningful space (Lewicka, 2011), while home is understood to signify a particularly important place of belonging (Tuan 1974, Relph 1976). Historically, it was argued that mobility weakens attachment to place (Relph 1976), however, as already mentioned, the scale of contemporary mobility has unsettled many of the certainties that once prevailed about belonging, identity and place attachment. We live in a highly mobile age of 'hypermobilities' 
(Urry 2002) where it is possible for people to create strong ties with several places simultaneously (Gustafson 2006, Lewicka 2011). In consequence, binary distinctions between 'home' and 'away' are no longer tenuous. Equally, while the idea of 'home' clearly connotes a significant physical dimension, place is also profoundly socially constructed and attachment to place is often felt through its social dimensions (Lewicka 2011). Hughes and Allen's (2010), study of Irish diaspora living in Manchester found that among first generation Irish, the trip to Ireland was thought of in terms of a visit to friends and relatives and for particular occasions, as opposed to a trip back to some 'special place'. Durko and Petrick (2016) recently reviewed a diverse literature which concluded that family travel can build relationships, create memories and increase family bonds.

\section{METHODOLOGY}

Empirically, this paper draws on a study of The Gathering, a 2013 Irish tourism marketing initiative that encouraged people in Ireland to organise 'gatherings' aimed at attracting 'home' friends and families scattered across the globe. The data reported here were generated through a study conducted in two Irish counties (Kerry and Westmeath) and stems from a mixed methods approach that included in-depth interviews with people involved in the Gathering at county level and in organising individual gatherings $(\mathrm{N}=16)$, an online survey of gathering organisers ( $\mathrm{N}=73$ ), focus groups involving 33 people who had some kind of involvement with a gathering and an online survey with members of the Kerry diaspora who had come home $(\mathrm{N}=136)$. Thirty nine percent of event organizers claimed that friends and relatives overseas and the diaspora were their main target audience for their events. Key research questions posed related to the role of the Gathering in making and re-making social connections within extended, diasporic family groups.

\section{THE GATHERINGS}

To yield insight into the kinds of events under study, this section begins by presenting five sample cases. Together they are indicative of the kinds of gatherings hosted by hundreds of families across the country in 2013. Following the sample cases, the findings are analysed thematically.

The Dolan family gathering comprised a lunch in a local hotel. It was organised by Geraldine (aged 45-54) who lived in the 'home' place. Seventy family members accepted her invitation to come to the event, including three people from abroad. About 20 local family members attended. At the event Geraldine distributed a 
crossword she had devised with family clues. She spoke, remembering recently deceased family members, and then a member of each of the individual families present spoke. People shared stories and talked of times past. For children it was all about learning and appreciating where they have come from and what life was like in times past. Geraldine explained how for older people, the prospect of meeting up with other family members caused great excitement. It was also a useful networking opportunity and one young family member residing in the USA managed to secure employment through a family member at the Gathering.

In one of the towns studied, the Gaelic Athletic Association (GAA), a national sporting organization with a large number of clubs located in Irish communities overseas, reached out internationally to bring home five generations of members for a sports tournament that was described by a survey respondent as a meeting of 'the offspring that never met'. As one focus group respondent explained, this Gathering led to 'reunions and meeting old friends' which, he claimed 'lifted everyone's spirits'. It also led to new connections as one young emigrant surveyed reported bringing along eight friends to visit on his return 'home'.

Foley Family Gathering: Martin (aged 45-54 yrs) and three of his cousins had already been researching their family tree and so once the Gathering initiative was introduced they secured some funding, set up a Face Book page and a committee. Martin comes from a hotelier background and so has organised countless functions in the past, but never a family reunion. The support of the Gathering officer in the local authority helped a great deal in putting together their two day programme of events which included family meals, a display of old family photographs and information about where relatives were buried, etc., the sharing of family photographs, a bus tour of all the family graveyards, a scattering of recently cremated ashes, and a mass. Their 'Gathering' attracted 188 family members with about 70 of these coming from the USA and UK. Sixteen people that he had never previously met flew in from Chicago. The following year, his son spent a working holiday in Chicago and met up with these family members again. For Martin: 'It was $100 \%$ worthwhile organising the event, more than worth all the effort .... It was such 
a happy event, everyone entered into the spirit...it was extremely positive, we shared a happy time...'

The Smith Clan Gathering. Dermot (aged 55-64 yrs) has a long standing interest in genealogy and a professional interest in tourism, owning a tour company. He organised a gathering that attracted 80 family members from overseas and 300 from Ireland. Many of the international visitors had never been to Ireland before and had a real desire to find out where their ancestors came from. The event comprised a historical bus tour of all the places associated with the family name, a pig on a spit in the main square of the local town attended by 400 people, a genealogy roadshow, a talk from a local historian, and a tree planting ceremony honouring their ancestors on land donated by the Town Council. Dermot described the event as being 'profoundly emotional'. Some family members had met for the first time on the flight over from the USA. He said he will never forget the sight of multiple members of his family sitting in the town square on one of the afternoons, sharing information, trying to work out their family trees. From the family's Face Book page (600 family members) it can be seen that a $4^{\text {th }}$ Gathering is planned for 2018.

The Boatyard Workers Reunion in Dingle, Co. Kerry 'reignited connections' between people who hadn't spoken to each other in 15-20 years, despite the fact that some still lived in the same area. During the Reunion, former employees and colleagues 'met and reconnected' and data suggested that 'these connections will probably continue'. In preparation for the event, organizers 'sent out a call for old artifacts and replicas' associated with boat-making and were inundated with offers from the community. They staged an exhibition of old photographs as well as talks on bygone days. In addition to recreating social links that had been lost, the Reunion acknowledged the important role that the workers had played in the local economy. As a focus group respondent explained: 'the people working at the boatyard never realized their (own) importance and were never acknowledged or rewarded ... the Gathering helped this'.

\section{1 Formal and informal activity}


Evident from the above is the fact that all of the family gatherings were organised by amateurs and were modest in scale. Events overwhelmingly involved family members who were known to each other and so there was a good deal of familiarity and trust already established. As such, people were well disposed towards the idea of reciprocity, to sharing an emotional connection and to becoming more assimilated into the family group. Accordingly, the networking underpinning the activity was overwhelmingly informal. This notwithstanding, an important formal context supported, shaped, affirmed and encouraged the informal activity. The Gathering was an official, nation-wide initiative that was high profile and well-resourced. It was strongly branded and received very significant national media attention. Funding as well as an array of other supports including training, mentoring, advice, material supports, etc. were channelled through local authorities, and Gathering organisers liaised directly with the officials temporarily assigned to the initiative at county level. This formal layer was very important in allowing informal activity to emerge and flourish, as event organisers and focus group respondents explained, 'the community effort needs the support of outside professionals'; and results in 'empowering local people by giving them information (which) they then share... (and) get prouder of the place in the process'. Overall, the data showed that respondents found the support forthcoming to be encouraging and supportive, while the funding made available was also extremely useful. In addition, the Gathering initiative permitted, indeed encouraged, organisers to draw on other structures existing at community level: for example, one of the above case studies features an event that tapped into the structures (e.g. international network) and facilities (e.g. venues) of the GAA, a long established national sporting organisation; another tapped into the workforce of a now defunct workplace associated with a trade deeply rooted in a coastal town. Furthermore, in many of the family gatherings, as in two of the cases above, the organisers used professional skills and experience learned in the formal sector to enable their informal actions. Ultimately, however, the activity of the localised gatherings was very informal. Responses from organisers showed that few of the family gatherings were in receipt of funding. Some had taken advice, attended a meeting organised at county level, or availed of some material supports. As one organiser explained: 'this media was begun for me by the Godsend Office in Tralee whom I really commend for their helpful assistance understanding and advice and professional manner'. Yet, for the most part they operated on their own, in their localised setting, under the auspices of the national initiative.

Thus, in general, the data showed that the manner in which the Gathering initiative was structured facilitated the exchange of formal and informal knowledge in ways that proved to be 
vital for creating hundreds of successful local gatherings. While Moscardo (2007) argued that festivals contribute to regional development by fostering community involvement and building networks, here the events acted to strengthen family groups by stimulating active participation and networking among family members. They acted as catalysts, encouraging individuals to emerge as leaders within the context of their family group. Armed with formal support and encouragement, event organisers/leaders then tapped into the knowledge, resources and networks existing within the family group. Their initiatives appealed to family members' desires for shared emotional connections and integration (McMillan and Chavis 1986) and were met with reciprocity. These findings are helpful in the context of Pedrana's (2015) call for more research to distinguish between the formal and informal interactions that influence social capital in festival settings. They give insight into how both formal and informal means of information sharing and knowledge exchange characterise events, as Black (2016) has written about in respect of festivals.

\subsection{Social connectivity, bonding and bridging}

Several researchers have written about the intensification of social relations that characterises festivals (Aria and Pedlar 2003) and this was evident here. The social interactions stimulated by the events stretched through time, with intergenerational connections being very important. Equally, they extended horizontally across space, connecting individual family branches and family members living in different places. Respondents explained that for them, the Gathering gave people the chance 'to spend time with our people'; and was about 'reaching out to family and friends linked by name and blood'. People thought it 'was good for families', and that families 'really benefited ... it brought them together'. The Gathering gave 'them a reason to get together', something that they felt 'was good', and that they felt they 'so often delay'. 'It just prodded people to engage with people that hadn't been in contact with in a while, particularly people overseas', and provided 'good, honourable connectivity for the diaspora'. Families, one interviewee explained, '... really grasped the Gathering by the horns, and saw it as an 'opportunity to bring their loved ones home en masse and to have a celebration'. 'It created awareness of the need to reach out to emigrants'. For one interviewee, this meant that the multitude of family gatherings that happened in 'a small area ... created a great sense of solidarity and that won't go away. There will be a legacy: it helped strengthen family bonds, people will come back as they have reconnected with people and also the area'. These findings support arguments made by researchers like Duval (2003, p. 274) who explain that in the context of diaspora tourism, the return visit 'functions as a means to renew, reiterate and 
solidify familial and social networks'. They also offer very tangible insight into claims about the contemporary 'stretching out of social relations' (Larsen, Urry and Axhausen 2007) and about how relations of belonging and domesticity extend far beyond the physical site (Crang 2006).

While the gatherings studied primarily aimed to reconnect ties with 'home' for extended family members spread across distances, a very notable feature of the data was the inter-generational interactions and ties that they also engendered. In line with Quinn and Wilks (2017), this study shows the heterotopic, 'time out of time' quality of events. The data revealed how the gatherings forged relationships across family generations, with one focus group respondent 'sensing interaction between generations that didn't happen before - a natural thing, not a forced thing'. Interviews held with organisers revealed how the family gatherings had effectively accumulated layers of time by venerating and remembering past generations, story-telling, privileging older voices in after-dinner speeches, photograph displays, visits to graveyards, and visits to family homesteads and other significant 'home' places. This all resulted in a sharing and learning about people, places and events that were of significance in the family's story. There was a consciousness of the ephemerality of family relationships. Several respondents talked about wanting to meet up with family at occasions that were not funerals. One commented how 'it was a special occasion...27 Family members travelled from USA... some older may not make it next time'. These data support Duffy and Waitt's (2011) arguments about how celebratory gatherings such as these help sustain narratives of belonging. They do this partly by offering a means of remembering the past, and of reinventing multiple time honoured family practices and traditions.

These gathering events represented social networking in action. Repeatedly the data revealed the commitment and effort that people put into bringing their families together. Key tenets of social capital in the guise of obligations and reciprocity, trust and trust worthiness, shared constructions of reality, norms and values (Coleman 1988) were all apparent. The gatherings were characterised by information sharing of all kinds, attesting to Falk and Kilpatrick's (2000) argument that during social interactions people can draw upon all kinds of knowledge and identity resources to build social capital. Sharing family histories and knowing each other was key in underpinning the shared sense of belonging that came through in the data. The trust that characterises family networks was key in enabling the event organisers to connect with people, and to both assemble and disseminate family information across the family networks. All of these highly co-operative interactions deepened family ties. For some of those involved, family 
bonds were active and close, for others they had lapsed, weakened by time and distance. In these latter cases, the gathering events served to strengthen bonding ties that had been somewhat dormant. Thus, respondents everywhere spoke of reconnections, and of how their gathering 'helped strengthen family bonds', as 'people have reconnected with people and also the area', 're-attach(ed) to our roots in Ireland', brought 'together several factions of the family from throughout the country', 'gave us Canadian/American-Irish visitors a sense of family and belonging. Gave our Irish friends and family a sense of familiarity and kinship with us', 'many people abroad contacting me from Florida, Georgia, Vancouver, Calgary, Boston, Sydney and England as well as many parts of Ireland who are over the moon to have re-established lost contact to their Irish family-place and roots'.

Social bonding is conceptualised as being inward looking (Wilks 2011) and having exclusionist tendencies (Bourdieu 1986), and Putnam (2000), for example, has argued that to be socially sustainable, communities need both bonding and bridging capital. However, the distinction between bonding and bridging capital is not always easy to define. Here, it can be argued that because the events involved families, bonding capital prevailed. However, bridging was also present, as new introductions were made, family members met for the first time, and young family members were presented to older relatives. Respondents spoke about 'making many new ones (connections) with family members that I had not met before. We keep in touch on Facebook now', and about 'some very young first time visits and introductions'. At one gathering, 'a family of three arrived from the UK, they knew that they were part of the Crowley family but they didn't know who, and once they walked into the event they started making connections and yes, they were part of this particular family'. There was also a sense in the data that this bridging would continue, with several respondents noting that 'lots of them (extended family members) came to visit and this will continue', 'lots of groups are in constant contact with those that visited' which they felt 'will result in others visiting in the future as new connections are developed'. One interviewee talked of one family where the key instigator had identified '500 people on her family tree' spread across the USA and Australia, and attracted 45 people to travel from abroad for the event. She continued: 'They've all connected into the information that she has gathered and the tree and they were following the event and the information that she gathered through the website that she set up and through social media'. 
In all cases, the gathering events gave people an opportunity to learn about their family and very importantly, it gave them an opportunity to express commitment to active membership of that family unit, in line with Wamwara-Mbugua and Cornwell (2009), who noted how those who travel to international festivals tend to have a vested interest in developing a collective sense of identity. The intense social relations could be seen to have created a wide range of returns for both individual family members and for family units as a whole. These came in the guise of experiencing pure fun, enjoyment and pleasure in being in the company of one's extended family; acquiring learning; and developing useful contacts. Returns also came in the enhanced sense of well-being that accompanied (re)connecting with, committing to, engaging in and drawing upon the stability of the extended family network. Thus these findings support Falk and Kilpatrick's (2000) argument that as social connections build into networks they generate social capital which becomes a resource to be used by people in the networks. The data revealed several instances of what it means in practice to draw on 'identity resources' (Falk and Kilpatrick 2000 p.19), with some younger family members using their new family connections to ease their mobility through the diasporic home communities of family members living abroad and other family members reporting meeting up with extended family members on subsequent outbound trips.

A notable characteristic of the data generated was its emotional content. Granovetter (1973) wrote about strong ties in terms of their emotional implications and certainly, the (re)creation of family connections spoken off by the study participants had strong emotional overtones. In line with McMillan and Charvis' (1986) writings on sense of community, the emotional dimension of these events was deeply rooted in shared histories and in a shared desire to avail of the trust and reciprocity that characterised the family networks. It may be that the special atmosphere engendered by these factors created an intensity of emotion that was particularly powerful. Certainly, the events created overwhelmingly positive environments where people were able to have fun together, and as Van Zyl and Botha (2004) have argued, this is particularly important in creating positive social networks.

While the gathering events were short in actual duration, the data suggest that their presence in the life of family members spilled over into both a phase of excited anticipation and preparations beforehand, (doing archival research, gathering information, collecting email addresses, booking accommodation, buying new outfits to wear, making cakes, etc.) and 
translated into happy, sustaining memories for some time afterwards. As one respondent said: 'the memory will remain with family and encourage younger members to continue the reunion down through the generations'. Some of the gatherings, like one of the sample gatherings described earlier, became recurring events.

Thus far, the empirical evidence presented tells a very positive story of harmonious, constructive family relationship building, yet it would be naive to think that these families were tension-free. Amidst all the positivity, there were a few signs of tensions in the data, with one family member, for example, speaking of the resurgence of frictions that had existed prior to the emigration of a now-returned, family member. Signs of tensions were very limited, however, although clearly, as the family members in attendance had elected to be there, it is likely that they were already positively disposed towards the family group. Perhaps those who felt otherwise had stayed away.

\subsection{Cultural and place identity}

Finally, but very importantly, amidst all the social networking and social bonding evident, a strong process of identity building was at play. Referring to people who had returned, one focus group participant explained: 'I think it gave people back their own identity. People had left an area and lost touch and I think it brought them back to the areas they were from and restored old affiliations'. Another spoke from the perspective of family members who remained in the home place saying 'it's almost as if we are minding the place for those that have gone: we are a caretaker'. As one respondent summarised: 'the Gathering has re-affirmed who we are - people - family - place - past \& present'; this 'pride in their community, pride in their own family' could be seen to be closely intertwined and in turn was closely linked to a sense of pride in place itself. As one interviewee said 'it also generated great spirit and pride and smaller communities became aware of their own ability, they saw what they could achieve and gave them great selfbelief'. The desire to identify collectively as a family unit was communicated very clearly and often very emotively. One respondent tried to capture the meaning of their family gathering by saying 'this is us, our history, our people doing it, we feel for those who can't come, we feel them away from us'. The desire to identify collectively was accompanied by a sense of pride. As one person explained: 'the celebration of our family, heritage and place .... of which I was always proud, but now I'm a pain in the ass proud'. These data very much echo other studies linking festivals and events to the development of various forms of group and place identity (Derrett 2003, Matheson 2005). 
While people were drawn to participate in the Gathering because of commitment to their family, this social content was intimately entwined with connections to the place that family members understood to mean 'home', whether they physically lived in this place or not. All of the gathering events were located in significant places which had an emotional pull for the families. Activities were planned so as to celebrate, venerate and remember places of import in family history, and it was clear that the process of remembering and sharing stories and knowledge was momentous for people in the home place as well as for those returning. Referencing various gatherings, focus group participants explained that 'it gave local people that acute sense of local history and culture'; 'raised a new importance to who you are and where you come from'; 'boosted interest and knowledge about their own place'; and caused 'the locals to become more exposed to their own heritage in the process'. Thus, all of these activities could be seen to be actively reconstructing collective identity and were all rooted in places that were safe and trusted by family members who felt connected to them. In line with Wilks and Quinn (2016), place was a very important element underpinning the stability of the social interactions and networking evident.

While the events seemed quite informal and varied in content, they shared many ritualistic aspects in respect of honouring, remembering and sharing family members, values and traditions. Gatherings of people at festivals have their origins in religious and spiritual rituals (Ravenscroft and Matteucci 2003). According to Collins (2004, p. 7) rituals are 'a mechanism of mutually focused emotion and attention producing a momentarily shared reality, which thereby generates solidarity and symbols of group membership'. The sample gatherings presented earlier show how ceremonial aspects were incorporated to remember and honour the dead (e.g. tree planting, visits to graveyards, building family trees, etc.) This was exactly what respondents were hoping for as they strove to connect with their families. One respondent explained that she wanted 'to honour my ancestors that are buried there, both parents, brother, grandmother, etc.' Two of the sample cases revealed the strong religious dimensions that characterised many of the gatherings in the guise of religious ceremonies and visits to cemeteries to remember deceased ancestors. While gatherings were informal, they were very ordered: respecting elder generations by giving them voice to recall stories and memories; seeking out and displaying family photographs and other documents for younger members of the family to experience; respecting divisions within families by acknowledging different branches in the sharing and display of family photographs and information, and sharing out the 
roles to be played by family members during the celebrations. Constructing this order was important in terms of establishing norms of due deference and respect, building and rewarding trust and reciprocity, and affirming shared values.

\section{CONCLUSION}

Back in 2001, Nicholson and Pearce called for greater attention to be paid to the enhanced socialization opportunities that many events provide, on the basis that events are quite distinct phenomenon, not simply just a form of tourism activity. This paper concurs, pointing to the important role that events can play in fostering social connectivity within extended families. Very little research has been conducted on events and families and so the research reported here is exploratory. The empirical data reported shows that celebrations like these family gatherings offer opportunities for actively remembering and renewing the past, affirming and reconnecting family ties, and reproducing emotional, spiritual and physical senses of belonging for extended family groups. Existing family ties were strengthened and new ties created within extended families separated by time (inter-generation) and by space (multiple residential locations) in ways that sustained beyond the time-bound hosting of the actual event.

Very importantly, the significance of the connectivity was felt not simply by those returning to the 'home' place but also by those who were still based there. In terms of future research this points to the need to study not only those who seek to reconnect with their families of origin in the 'home' place but also those who strive to reach outwards to their extended family members scattered elsewhere. While the activities that comprised the gatherings were all premised on familial ties which inspired trust and encouraged social connectivity, they were all firmly rooted in a 'home' place that held universal significance for the families as units. These places were central to the celebrations, and created a shared bond and an underpinning stability that inspired trust and reciprocity and helped to draw people together even when extended family members had never actually met in person before. In effect, the 'home' places provided a safe and somewhat sacred haven within which family members could connect.

Social capital ideas were useful in unravelling the social networking on which the events were premised. These extended family groups were characterised by ties of varying strengths, including some ties that had been broken. Through the events, family members variously strengthened existing ties, rekindled lapsed ones and found others they hadn't realised existed. 
Most of the data show evidence of bonding, although there was also quite an amount of bridging across both family generations and across family units living in different places. Whether this can technically be thought of as bridging capital given the underlying context of shared family connections, histories, knowledge and values is a little unclear: the blurring of bonding and bridging capital at issue requires further investigation. There was some evidence that the social capital generated led to benefits for individual family members travelling away from the 'home' place in terms of contacts, support and further networking. For the families as a whole, the bonding and bridging could be both seen and felt as an energising, deepening and strengthening force. Through their interactions, family members could be seen to be drawing on a host of shared understandings to reproduce individual, family and place identities (Falk and Kilpatrick 2000).

Echoing other research on festivals and identity at the community level (Finkel 2010) the findings pointed to wider dynamics and processes informing the reproduction of group solidarity, a shared sense of belonging, and identify affirmation and renewal. Understanding these processes and particularly the emotional bonding at play requires a deeper understanding of the interplay between social capital and concepts like sense of community, ritual, family and home. This is a task for further research. Finally, while this study was strongly focused on smallscale, informal events, the findings showed how contextualising formal structures played an important role in encouraging network building. For policy makers this points to the merits of devising mechanisms to support small-scale, informal social gatherings so as to foster the kinds of private and public goods identified in this study.

\section{REFERENCES}

Aria, S., and Pedler, A. (2003). Moving beyond individualism in leisure theory: A critical analysis of concepts of community and social engagement, Leisure Studies, 22 (3), $185-202$.

Backman, K. F., Backman, S. J., Uysal, M., \& Sunshine, K. M. (1995). Event tourism: an examination of motivations and activities. Festival Management and Event Tourism, 3(1), 15-24.

Black, N. (2016). Festival connections. How consistent and innovative connections enable smallscale rural festivals to contribute to socially sustainable communities. International Journal of Event and Festival Management, 7(3), 172-187.

Bourdieu, P. (2002 [1986]). The forms of capital, in, Biggart, N. W. (Ed), Readings in Economic Sociology. Malen, Mass: Blackwell. Pp.280-291. 
Coleman, J. S. (1988). Social capital in the creation of human capital. American Journal of Sociology 94 Supplement, S95-120.

Coles, T., \& Timothy, D. J. (2004). Tourism, Diasporas and Space. London: Routledge.

Crang, M. (2006). Circulation and emplacement: the hollowed-out performance of tourism. In C. Minca, and T. Oakes (Ed.s), Travels in Paradox: Remapping tourism. (pp.47-64). Oxford: Rowman and Littlefield.

Derrett, R. (2003). 'Making sense of how festivals demonstrate a community's sense of place,' Event Management, 8(1), 49-58.

Duffy, M. and Waitt, G. (2011). Rural festivals and processes of belonging. In C. Gibson, J. Connell, Ed.s), Festival Places: Revitalising Rural Australia. (pp. 44-57).Bristol: Channel View Publications.

Durko, A. M. and Petrick, J. F. (2013). Family and relationship benefits of travel experiences: a literature review, Journal of Travel Research, 52(6), 720-730

Duval, D. T. (2003). When hosts become guests: return visits and diasporic identities in a Commonwealth Eastern Caribbean community. Current Issues in Tourism, 6 (4), 267-308.

Etemaddar, M. Duncan, T. \& Tucker, H. (2016). Experiencing 'moments of home' through diaspora tourism and travel, Tourism Geographies, 18(5), 503-519.

Falk and Kilpatrick (2000). What is Social Capital? A Study of Interaction in a Rural Community, Sociologia Ruralis, 40(1), 87-110

Finkel, R. (2010). 'Dancing around the ring of fire': social capital, tourism resistance and gender dichotomies at Up Helly Aa in Lerwick, Shetland, Event Management, 14 (4), 275-285.

Foster, K. and Robinson, P. (2010). A critical analysis of the motivational factors that influence event attendance in family groups. Event Management, 14, 107-125.

Granovetter, M. S. (1973). The strength of weak ties, American Journal of Sociology, 78(6), 13601380.

Gursoy, D., Kim, K and Uysal, M. (2004). Perceived impacts of festivals and special events by organizers: an extension and validation. Tourism Management, 25, 171-181. 
Gustafson, P. (2006). Place attachment and mobility. In N. McIntyre, \& K. E. McHugh (Eds.), Multiple dwelling and tourism: Negotiating Place, Home and Identity (pp.17-31). Oxon: CAB International.

Habermas, J (1972). Toward a Rational Society. J. Shapiro, (Trans) London: Heinemann.

Hughes, H. and Allen, D. (2010). Holidays of the Irish diaspora: the pull of the 'homeland'? Current Issues in Tourism, 13(1), 1-19.

Larsen, J., Urry, J. and Axhausen, K. W. (2007). Networks and tourism: mobile social life. Annals of Tourism Research, 34(1), 244-262.

Lavenda, R. H. (1997). Corn Fests and Water Carnivals: Celebrating Community in Minnesota. Washington, D.C.: Smithsonian Institution Press.

Lee, C. K. (2000). A comparative study of Caucasian and Asian visitors to a cultural expo in an Asian setting. Tourism Management, 21(2), 169-176.

Lee, H. (2004). 'Second generation' Tongan transnationalism: hope for the future? Asia Pacific Viewpoint, 45(2), 235-254.

Lee, I.S., Arcodia, C. Lee, T.J. (2012). "Multicultural festivals: a niche tourism product in South Korea", Tourism Review, 67(1), 34-41.

Matheson, C. M. (2005). 'Festivity and sociability: a study of a Celtic music festival,' Tourism Culture \& Communication, 5, 149-163.

McMillan, D.W. and Chavis, D.M. (1986). Sense of community: a definition and theory, Journal of Community Psychology, 14(1), 6-23.

Mohr, K., Backman, K. F., Gahan, L. W., \& Backman, S. J. (1993). An investigation of festival motivations and event satisfaction by visitor type. Festival Management \& Event Tourism, 1, 8997.

Mollitor, F., Rossi, M. and Branton, L. (2011). Increasing social capital and personal efficacy through small-scale community events, Journal of Community Psychology, 39 (6): 749-754. 
Morgan, N. Pritchard, A. and Pride, R. (2003). Marketing to the Welsh diaspora: The appeal to hiraeth and homecoming. Journal of Vacation Marketing, 9(1), 69-80.

Moscardo, G. (2007). Analyzing the role of festivals and events in regional development. Event Management 11(1-2), 23-32.

Moufakkir, O. (2011). The role of cultural distance in mediating the host gaze. Tourist Studies, 11(1), 73-89.

Mykletun, R. (2009). Celebration of extreme playfulness: Ekstremsportveko at Voss, Scandinavian Journal of Hospitality \& Tourism, 9(2/3), 146-176.

Nicholson, R., \& Pearce, D. G. (2001). Why do people attend events: A comparative analysis of visitor motivations at four south island events. Journal of Travel Research, 39, 449-460.

Pedrana, M. (2015). The case of Skieda in Livorno, Italian Alps. In A. Jepson and A. Clarke, (Ed.s) Exploring Community Festivals and Events. Abingdon, Oxon: Routledge.

Prentice, R. and Anderson, V. (2003) Festivals as creative destination. Annals of Tourism Research 30, 7-30.

Putnam, R. D. (2000). Bowling Alone: the Collapse and Revival of American Community. New York: Simon and Schuster/Touchstone.

Quinn, B. and Wilks, L. (2017). Festival heterotopias: Spatial and temporal transformations in two small-scale settlements. Journal of Rural Studies, 53, 35-44.

Quinn, B. and Wilks, L. (2013). Festival connections: people, place and social capital, in, G. Richards, M. P. de Brito, and L. Wilks, (Eds) Exploring the Social Impacts of Events, (pp. 15 - 30). Abingdon, Oxon: Routledge.

Rao, V. (2001).Celebrations as Social Investments: Festival Expenditures, Unit Price Variation and Social Status in Rural India. Journal of Development Studies, 38(1), 71-97.

Ravenscroft, N. and Matteucci, X. (2003). The festival as carnivalesque: social governance and control at Pamplona's San Fermin fiesta, Tourism, Culture \& Communication, 4(1), 1-15. 
Relph, E. (1976). Place and Placelessness. London: Pion Limited.

Rodríguez-Pose, A., Storper, M. (2006). Better rules or strongest communities? On the social foundations of institutional change and its economic effects. Economic Geography 82, 1-25.

Scheyvens, R. (2007). Poor cousins no more: valuing the development potential of domestic and diaspora tourism. Progress in Development Studies, 7(4), 307-325.

Schofield, P. and Thompson, K. (2007). Visitor motivation, satisfaction and behavioural intention: The 2005 Naadam Festival, Ulaanbaatar. International Journal of Tourism Research, 9, 329-344.

Taylor, C., McArdle, F., Richer, S., Brennan, C. and Weier, K. (2006). Learning partnerships parents of young children: studying the impact of a major festival of early childhood in Australia. European Early Childhood Education Research Journal, 14(2), 123-132.

Uysal, M., Gahan, L. and Martin, B. (1993) An examination of event motivations: a case study. Festival Management \& Event Tourism. 1(1), 5-10.

Van Zyl, C. and Botha, C. (2004). Motivational factors of local residents to attend the Aardklop national arts festival. Event Management, 8(4), 213-222.

Wamwara-Mbugua, W. and Cornwell, T. B. (2009). Visitor motivation to attending international festivals, Event Management 13(4), 277-286.

Wilks, L. (2011). Bridging and bonding: social capital at music festivals. Journal of Policy Research in Tourism, Leisure and Events, 3(3), 281-297.

Wilks, L. and Quinn, B. (2016). Linking social capital, cultural capital and heterotopia at the folk festival. The Journal of Comparative Research in Anthropology and Sociology (COMPASO), 7, 2339. 
